\title{
IDENTITATEA MORALĂ A PERSOANEI UMANE ÎN CONŞTIINȚA MISIONARĂ A BISERICII
}

\author{
Liviu Stanciu*
}

\begin{abstract}
Human Person's moral identity in the missionary consciousness of the Church. This study treats the essential role of the human person as a part of the mystical Body of Christ - the Church. The moral identity of the person reveals the true place of the human being in the creation of God. But as an "administrator" of this "very good" work of the Creator, disrespecting God's commandments man felt down in a state in which he rejects the Creator and replaces Him with surrogates. The sacrifice of Jesus Christ restores the real meaning of the human life and gives to the humanity a new purpose to reach for - the unification with God by practicing the virtues revealed by the Person of Christ. Having Christ's Person as the supreme example of holiness, man, as the image of his Creator, has to reach constantly to achieve the likeness of God.
\end{abstract}

Keywords: person, moral identity, human existence, Church, image and likeness.

\section{Introducere}

Una dintre problemele cele mai dificile cu care se confruntă lumea de astăzi este faptul că societatea de consum în care ne aflăm a încercat şi a izbutit cu succes să disloce, aproape insesizabil, dar cu efecte nocive ireversibile, persoana umană de existența ei eclezialmorală. Există astăzi un conflict deschis, declarat, între două entități

* PhD candidate, Faculty of Orthodox Theology, „1 Decembrie 1918” University, Alba Iulia, secretary of the Orthodox Archdiocese of Alba Iulia 
teologico-sociologice: identitatea morală a persoanei şi utilitarismul care presează din punct de vedere social persoana. Într-o relaţie încordată cu divinitatea şi în cadrul unor relații interumane defectuoase, s-a pierdut sensul comuniunii personale, sensul regăsirii în celălalt. Pozând într-un incontestabil administrator al creației universale, omul postmodern a transformat sensurile existențiale raportate la Dumnezeu şi la omenire în sensuri imediate, care s-au deteriorat mai târziu într-un pragmatism utilitarist. În acest punct s-a pierdut noțiunea de „responsabilitate etică” față de natură şi umanitate. Mascându-i-se responsabilitățile existențiale, demnitatea umană a fost violată şi abuzată până în stadiul de izolare. Legea morală stabilită de către Dumnezeu la facerea lumii a fost aruncată într-un sertar temporal, care nu se mai încearcă a fi deschis. Practic, sentința autodegradării morale a orbit şi ceea ce se mai întrezărea ca fiind „original”, „dat fiinţial”, „,chip” al Divinului.

Existența umană a fost ruptă progresiv de Ființa supremă. Distanța de la „chip” la ,asemănare” s-a adâncit până când a avut loc restaurarea ființei prin Întruparea Fiului lui Dumnezeu. În acel punct, sensurile creaționale au revenit la normal, însă, cu trecerea timpului, lumea a divorțat din nou de Dumnezeu şi s-a îndepărtat de efectele Învierii. Omenirea s-a izolat de Creator, atât în teorie, cât şi în viețuire. Postmodernităţii îi e mai bine fără Dumnezeu: nu mai aplică „stresul moral”, acesta fiind înlocuit cu stresul social, Biserica a fost izolată în comunităţi ermetice retrograde, ignoranța şi indolenţa au fost secondate de o media agresiv imorală etc. Existența liberă s-a regăsit în libertinism, s-a separat de Creator, fără să mai recunoască Principiul liber care a făcut-o vie ${ }^{1}$. „Omul a fost redus la nevoile elementare biologice şi culturale, ale supraviețuirii lui (hrana,

\footnotetext{
1 „Lumea creată, cu toată materialitatea ei, a fost aşezată de Creator la picioarele lui Adam ca lume sacramentală" (vezi Pr. Lect. Dr. Mihai Himcinschi, Misiunea Bisericii într-o societate abundent capitalizată, în vol. „Spiritualitate şi consumism în Europa unită”, Alba Iulia, Edit. Reîntregirea, 2004, p. 383.)
} 
reproducerea), la jocul pasiunilor fundamentale create în jurul acestor nevoi" 2 .

Teologia ortodoxă este o teologie a persoanei, o teologie a celuilalt reflectat în mine, a răspunsului iubirii la iubirea ne-egoistă, care se împlineşte în altul. Redusă doar la statutul de individ, persoana umană este un simplu actor social, o piesă mai mult sau mai puțin utilă într-un joc al existenței limitate, o entitate amorfă, supusă de nevoile fiziologice, slab înarmată cu conştiință, izolată de ideea de alteritate. Lipsită de relația cu Creatorul, ființa umană este, din toate punctele de vedere, un instrument exploatabil fizic şi psihic. Fără săşi mai dorească a cunoaşte Principiul suprem al existenței sale, omul se micşorează pe sine sub condiția de animal, o conştiință anulată. „Orice gândire, fie filosofică, fie teologică, e obligată să afirme un Principiu ca determinare a existenței. Dar gândirea teologică arată că omul nu e persoană, şi lumea nu e reală dacă nu sunt creația liberă a unui Principiul liber: nu individ puternic, precum în gândirea elină, $c i$ persoană (noțiune eminamente creştină, total absentă în păgânism), adică Libertate absolută, mai presus de orice necesitate, chiar de ființă sau existență"’3.

\section{După chip şi asemănare - fundamentul identitar al persoanei}

Termenul de persoană vine din latinescul persona, derivat din grecescul prosopon care desemna, în teatrul grec din Antichitate, masca teatrală a actorului ${ }^{4}$, rolul acestuia, dar şi actorul însuşi. Ulterior, termenul a fost acceptat ca noțiune care definea omul ca entitate singulară în raport cu alte entități. Acelaşi parcurs 1-a avut şi cuvântul rusesc licina, care a devenit, cu timpul, licinosti,

2 Diac. Ioan I. Ică Jr., Îndumnezeirea omului. P. Nellas şi conflictul antropologiilor - introducere la Panayotis Nellas, Omul - animal indumnezeit. Perspective pentru o antropologie ortodoxă, Sibiu, Edit. Deisis, 1999, p. 6.

${ }^{3}$ George Remete, Ființa şi credința, vol. I, Ideea de ființăa, Bucureşti, Edit. Academiei Române, 2012, p. 108.

${ }^{4}$ Enciclopedie de filozofie şi ştiințe umane, Bucureşti, Edit. All, 2004, p. 814. 
personalitate. Privită din perspectiva tradiției occidentale, persoana reprezintă ,categoria filosofică ce permite subsumarea sufletului şi a trupului gândite ca elemente indisociabile, dotate cu rațiune şi perfectibile" ". Definind-o sociologic, afirmăm că persoana umană desemnează sistemul de însuşiri, relații şi calități psihosociale care dau identitate socială individului. Persoana vizează ființa concretă cu o identitate socială determinată (nume, familie, loc şi dată de naştere, statut social etc.) şi deținând o anumită poziție în cadrul sistemului social, cu anumite drepturi şi obligaţii de care este conştientă. Ea desemnează, de asemenea, o individualitate conştientă de sine şi recunoscută de către ceilalți. Persoana umană este corespondentul în plan social al individului din planul biologic.

În teologia ortodoxă, ,prin cuvântul persoană definim o realitate anaforică, aceea a raportării ... Prepoziția grecească (n.n.) $\pi \rho o ́ \varsigma$ («către, spre, în direcția»), împreună cu substantivul $\omega ̋ \psi$, care înseamnă «privire» $(o ̋ \mu \alpha)$, «ochi» $(o \phi \theta \theta \alpha \lambda \mu o ́ s)$, «înfăţişare»,

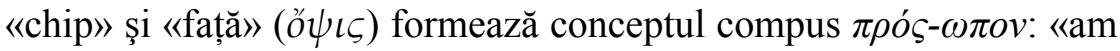
privirea, fața ațintită spre cineva sau spre ceva» ... Cuvântul, aşadar, a funcționat inițial ca determinare a unei raportări directe, nemijlocite, ca determinare a unei relații" ${ }^{6}$. Sfinții Părinți au folosit termenul de persoană, în primă fază, ,cu referire la Dumnezeu şi, desigur, la cele trei Persoane ale Sfintei Treimi. A trebuit să fie parcurs un întreg proces pentru a se ajunge la formularea faptului că Dumnezeul Treimic, Tatăl, Fiul şi Sfântul Duh, sunt Persoane Ipostasuri aparte, dar care au o esență sau o substanţă comune"7.

Cuvintele de la Facere 1, 26: „Să facem om după chipul şi asemănarea Noastră" reprezintă fundamentul existenței persoanei umane. Avându-şi originea în planul trinitar de manifestare a iubirii, „chipul” este conceput după modelul personal trinitar. Actul de

5 Vezi studiul Personne, în „Encyclopedia Universalis”, apud M. Dinu, Fundamentele comunicării interpersonale, Bucureşti, Edit. All, 2004, p. 7.

${ }^{6}$ Christos Yannaras, Persoană şi eros, Bucureşti, Edit. Anastasia, 2000, p. 21.

${ }^{7}$ Hierotheos, Mitropolit de Nafpaktos, Persoana în tradiția ortodoxă, trad. de Prof. Paul Bălan, Bacău, Edit. Bunavestire, 2002, p. 60. 
creație al lui Dumnezeu este, în fapt, o chenoză a Sfintei Treimi în angrenajul preexistenței umane. După ce sfatul treimic este pus în aplicare şi acțiunea de ,înnodare” a loghiilor seminale dă naştere lumii întregi, omului îi este dedicată o altfel de mişcare creațională o mişcare gândită dintr-o iubire absolută, dornică de expansiune, dar nu o expansiune calculată, matematică, juridică, ci atotiubitoare, de Părinte. „În teologia răsăriteană, Dumnezeu, deşi rămâne etern Creatorul şi Atotţiitorul, este, mai întâi, Părintele. Acesta nu calculează copilul, ci îl iubeşte. Minima experiență a oricărei creații personale ne arată că a crea nu înseamnă a calcula, ci a iubi”,

Dumnezeu relevă, prin cuvintele din Facere 1, 26, importanța actului creaţional şi scopul eshatologic al acestuia: importanţa o demonstrează punând în aplicare planul intratreimic de creare a lui Adam, iar scopul eshatologic este demonstrat de încărcătura divină pe care o dă ființei - aceea de a ajunge „,ca Noi”, „după chipul şi asemănarea Noastră". Este deosebit de important faptul că, în chenoza creației, Dumnezeu, ca Persoană supremă, ,„pliază” chipul Său pe chipul ființei create, adică pe persoana umană ${ }^{9}$. Felul în care se produce acest act nu poate fi explicat, pentru că nu cunoaştem esenţa lui Dumnezeu, ci ştim doar energiile cu care Se face cunoscut. Dar actul creativ presupune ,donarea” a ceva din Dumnezeu omului, pe care 1-a făcut dintr-o iubire ce „exploda” de creativitate. „Toți Părinții Bisericii, atât cei din Răsărit cât şi cei din Apus, sunt de acord să vadă în faptul creaţiei omului după chipul şi asemănarea lui Dumnezeu o oarecare rânduire de mai înainte stabilită, un fel de potrivire dintru început între ființa omenească şi dumnezeiască”. ${ }^{10}$

\footnotetext{
${ }^{8}$ George Remete, op. cit., p. 116.

9 Trebuie făcută aici distincția între ,ființă (das Sein) şi fiind (sau ființare, das Seiende): ființa e „ce”-ul, iar fiindul e „cum”-ul ca existență. Ființa este desemnată prin termenii to on, ousia sau essentia, iar existența prin substanția sau existentia" (vezi George Remete, op. cit., p. 59). Aşadar, omul a luat ca model de existență subzistența lui Dumnezeu.

${ }^{10}$ Vladimir Lossky, Teologia mistică a Bisericii de Răsărit, Bucureşti, Edit. Anastasia, f.a., p. 143.
} 
Palpabilă, recognoscibilă, consecinţa actului de creaţie este că omul a fost gândit de către Dumnezeu ca persoană dinainte de a fi fost creat. Ideea de om-persoană exista în mintea Sfintei Treimi încă din faza de plan de creatie, deci atemporal. În momentul creației, el a devenit persoană în act ${ }^{11}$, conştientă de sine şi de valoarea sa, exact ca Dumnezeu, încărcându-se de o responsabilitate eshatologică egală cu greutatea darului primit. Părintele Dumitru Stăniloae afirmă: „Noi suntem făcuți pentru eternitate, pentru că noi aspirăm ca nişte înăbuşiţi după infinitate, după absolut" ${ }^{\prime 2}$. Fiecare act al omului creat este o „,ieşire din sine” spre Creator şi creației, spre un „,celălalt”, dar pervertirea prin păcat a dus la degradarea ,ieşirii din sine" spre Dumnezeu, la plecarea din Dumnezeu pentru ,intrarea în sine” rezultatul egoist al păcatului. S-a ajuns apoi la o pervertire radicală, dusă până la refuzul lui Dumnezeu, la scoaterea Creatorului din ecuația existențială, pentru că prezența Acestuia producea un deranj metafizic acut în ceea ce priveşte săvârşirea liberă a păcatului. Libertatea şi-a schimbat definiţia, iar creatul L-a eludat pe Creator, pretinzând o libertate nefavorabilă răspunderii sale eshatologice.

Omul a ieşit din mâinile lui Dumnezeu ca fiu al Său ${ }^{13}$, ca microcosmos $^{14}$ şi ca microteos, ființă completă, posedând o demnitate dumnezeiască, unică, de împărat. A fost creat integru, total, fără să mai aibă nevoie de alte intervenții pentru a deveni complet. El a ieşit direct „suflet viu”, el este suflet, este corp, este $\psi v \chi \eta ́$, nefeş. Vladimir Lossky spune că „,eea ce obține omul în

${ }^{11}$ Este imposibil să credem că Dumnezeu ar fi gândit o maşinărie cu care să nu poate să intre în contact. Ar însemna că întreaga creație a fost gândită ,greşit” şi că eroarea nu a putut fi corectată. Acest lucru ar duce, logic, la ideea unui Dumnezeu imperfect.

12 Pr. Dumitru Stăniloae, Teologia Dogmatică Ortodoxă, vol. 1, Bucureşti, EIBMBOR, 2003, p. 14.

13 „Duhul mărturiseşte împreună cu duhul nostru că suntem fii ai lui Dumnezeu" (Rom. 8, 16).

14 „Omul este un microcosmos în sensul că el formează frontiera care uneşte categoriile vizibile şi spirituale ale existenţei şi care, după cădere, contribuie la reunirea lor" (Irineu Pop Bistrițeanul, Chipul lui Hristos în viața morală a creştinului, Cluj-Napoca, Edit. Renaşterea, 2001, p. 28). 
calitatea sa de creatură a unui Dumnezeu-Persoană este demnitatea"15. Duhul Sfânt activează în „,chipul” proaspăt creat toate calitățile pe care Sfânta Treime le-a gândit şi le-a pus în om la facerea $\mathrm{sa}^{16}$. Prin urmare, Adam, cel dintâi creat, este o plinătate de harisme, încărcat de daruri directe, coborâte chiar din logica creațională a iubirii lui Dumnezeu. Fără a cunoaşte mândria posedării acestora, Adam era, practic, pe o scară foarte înaltă a epectazei desăvârşirii, moralitatea actelor sale identificându-se cu persoana sa şi având o conştiință care deja începuse să relaţioneze, ducând persoana în fapt al comuniunii: „Conştiință înseamnă o relaţie $a$ priori cu obiectele ... conştiința este o calitate «personală»" "17.

Ca Persoană supremă, Dumnezeu este privit de către om ca valoare supremă atât prin ,ceea ce Acesta este” (Ieş. 3, 14), cât şi prin ceea ce El a dat persoanei umane. In relația de creație Dumnezeu-om nu există egoism, ci doar o deplină responsabilitate divină care, după creație, devine eshatologie personală umană. Conştientizarea valorii persoanei umane este revelată tot în Facere, când Adam, cu un „,chip” ce manifestă o inteligență debordantă, deci un „,chip” în curs de actualizare, în curs de ,,asemănare”, pune nume fiecărei existențe: el este deplin conştient de „cantitatea” de dumnezeire aşezată în persoana sa, aşa că îşi arogă deja calitatea de stăpân al lumii, substituindu-se, cu mandat divin autentic - Creşteți şi vă înmulțiți, şi umpleți pământul şi-l supuneți (Fac. 1, 28) - dar într-o complementaritate supusă, Creatorului. El „continuă” opera de creație, ajutat de o inteligență fantastică a raţiunii lucrurilor: „Raţiunile lucrurilor se descoperă conştiinței umane, având să fie

${ }^{15}$ Vladimir Lossky, După chipul şi asemănarea lui Dumnezeu, Bucureşti, Edit. Humanitas, 2006, p. 121.

${ }^{16}$ Pnevma, ruah, duhul, adică ,suflarea dumnezeiască” este organul comuniunii cu transcendentul, ceea ce nu este cu putință decât numai în funcție de „o comuniune de esență”, legată de acel ceva tainic din noi, care ne îngăduie să afirmăm că „noi suntem din neamul Lui” - Fapte 17, 28 (vezi Paul Evdochimov, Ortodoxia, trad. de Dr. Irineu Popa, Arhiereu vicar, Bucureşti, EIBMBOR, 1996, p. 70).

${ }^{17}$ Christos Yannaras, op. cit., p. 23. 
asimilate de aceasta, concentrate în ea; se descoperă ca având ca centru virtual conştient al lor rațiunea umană, şi ajutând-o să devină centrul actual al lor" ${ }^{\prime 18}$.

Proaspăt creat, planul era ca el, aflându-se permanent în atmosfera de taină a prezenței Sfintei Treimi, să conştientizeze limpede, prin comunicare personală directă, toată logica iubirii lui Dumnezeu. El înțelegea perfect că ,universul e încărcat de mesaje şi semnificații, pentru că fiecare făptură concretizează în sine şi manifestă simbolic, la nivelul ei, principiile existenței"19. Tot ce era în jurul lui Adam era „bun foarte” (Fac. 1, 31). „Ele erau «bune foarte», pentru că erau revelația chipului bunătăţii Sale; se mişcau în obârşia şi finalitatea lor, săvârşind o taină, un sacrament al binelui" ${ }^{20}$. „Chipul” avea toate mijloacele pentru a ajunge la ,asemănare”, inclusiv încărcătura sa morală, identificată cu propria persoană. Om total, integru, sobru din punct de vedere moral, inteligent, cu o conştiință a lucrurilor foarte dezvoltată, Adam se dezice de cea mai uşoară regulă a creației - ascultarea - şi cade în neantul dezlipirii de Dumnezeu. Conştiința se întunecă, persoana pierde valorile morale care o defineau şi care proveneau direct din ,parfumul gurii lui Dumnezeu”, care i-a umflat nările de viață. Sobrietatea sa de om total se pierde când încearcă să se disculpe aruncând vina, iar inteligența i se scurtează şi ajunge să dărâme tot ceea ce a clădit Creatorul în ființa lui.

\section{Iisus Hristos, Persoana divină văzută - fundamentul şi izvorul existențial-moral al persoanei umane}

Taina persoanei se revelează în Persoana văzută a Mântuitorului nostru Iisus Hristos. Prin Întrupare, Dumnezeu devine om şi-L vedem ca om, ca persoană care deține ontologic toate virtuțile necesare îndumnezeirii. La restaurarea lumii de către

\footnotetext{
${ }^{18}$ Pr. Dumitru Stăniloae, op. cit., p. 12.

19 Pr. Constantin Galeriu, Jertfă şi răscumpărare, Bucureşti, Edit. Harisma, 1991, p. 78.

${ }^{20}$ Ibidem, p. 77.
} 
Hristos, se reinstaurează „noutatea” ontologică a creației, omul redevine o imago Dei spiritualizată, „chip şi revelare a lui Dumnezeu, locaş al absolutului" ${ }^{21}$, dar o imago cu puteri reinstaurate întru ființă de către Principiul suprem, de către Logosul divin întrupat, Care coboară chenotic şi adânc întru omenitate (adânc, pentru că ia de la zero întregul proces de înomenire: de la Bunavestire la Jertfă şi Înviere), dar care lucrează dumnezeieşte cele omeneşti şi omeneşte pe cele dumnezeieşti, cum spun Sfințiii Părinți. Întruparea Logosului este „,singurul lucru nou sub soare”, după cum se exprimă Sfântul Ioan Damaschin ${ }^{22}$. La umbra acestui „,singur lucru nou sub soare", creşte devenirea omului întru ființă tot ca principiu de noutate: o noutate morală, care îşi are izvorul în Persoana absolută făcută om, Care a împărtăşit totalitatea virtuților din sine către oameni, devenind Exemplul suprem de virtute şi desăvârşire (cf. Efes. 4, 13).

Actul Întrupării Cuvântului lui Dumnezeu, evenimentul central al Revelației divine, este, teologic vorbind, ,piatra cea din capul unghiului" a înțelegerii reale a relației lui Dumnezeu cu lumea, în general, şi cu omul, în special. Cunoaşterea Tainei şi a înțelesurilor Întrupării Logosului divin în lumea care ,prin El s-a făcut; şi fără El nimic nu s-a făcut din ce s-a făcut" $(I n .1,3)$ şi realizarea faptului că totul ființează datorită mişcării Lui înspre lume, pentru că ,întru El era viața, şi viața era lumina oamenilor” (In. 1, 4), constituie esența catafatică şi apofatică a întregii teologii creştine, în speță ortodoxă. Oricum am trata Taina Întrupării - din punct de vedere catafatic sau apofatic - concluziile pe care le-ar trage teologia ar fi aceleaşi: venirea Logosului în lume pentru mântuirea ei este un plan care nu aparține umanității, ci se află în mintea, în gândirea Sfintei Treimi înainte de a fi lumea, deci înainte de crearea omului.

După ce , «chipul substanței Tatălui» s-a revelat, asumându-şi natura umană ... Dumnezeul transcendent devine imanent lumii",23,

\footnotetext{
${ }^{21}$ George Remete, op. cit., p.151.

${ }^{22}$ Sfântul Ioan Damaschin, Dogmatica, cartea a III-a, trad. de Dumitru Fecioru, Bucureşti, EIBMBOR, 2005, p. 115.

${ }^{23}$ Vladimir Lossky, După chipul..., p. 6.
} 
Se face cunoscut ca Dumnezeu creator in persona, cu chip de om, tangibil, palpabil, mai uman decât orice om, în acelaşi timp om adevărat şi Dumnezeu adevărat. Dacă în Vechiul Testament, „Dumnezeu i S-a arătat lui Moise in conspectu - «în prezență», dar Moise nu poate să-L vadă" ${ }^{24}$, având parte doar de o „,vedere figurativă,25, în Noul Testament, Taborul reprezintă culmea revelației Cuvântului Întrupat, unde Dumnezeu realizează făgăduința făcută pe Sinai lui Moise - abia acum, Moise poate să-L vadă „la față”, secondat de către Proorocul Ilie. Referindu-se la această treaptă a revelației Cuvântului Întrupat, Sfântul Irineu de Lyon zice: „Cuvântul S-a făcut trup pentru ca tot ce există să-L poată vedea... pe regele său; şi, de asemenea, pentru ca lumina Tatălui să se reverse pe trupul Mântuitorului nostru şi din trupul Său să vină până la noi, ca omul să ajungă astfel la nestricăciune, fiind îmbrăcat în lumina Tatălui”26. Aici, trebuie să înțelegem că expresia „lumina Tatălui” nu se referă la ființa Treimii, pentru că „Dumnezeu este numit lumină nu după esența $\mathrm{Sa}$, ci după energia Sa”, după cum spune Sfântul Grigorie Palama ${ }^{27}$. Această lumină a lui Dumnezeu este harul divin, ce revelează în om calitățile morale ale Persoanei supreme şi care face posibilă legătura personală a persoanei umane cu Creatorul.

În toate actele văzute pe care Hristos le întreprinde, Se descoperă ca persoană, tocmai pentru a fi înțeles de către purtătorul chipului Său, omul. Însumate, manifestările lui Dumnezeu se concentrează în persoana Logosului Întrupat, purtător de rațiuni pe care le revelează umanului puțin câte puțin până la Tabor, în funcție şi de capacitatea umanului de a recepta atâta dumnezeire câtă purta în

${ }^{24}$ Vladimir Lossky, Vederea lui Dumnezeu, trad. de Maria-Cornelia Oros, studiu introductiv de diac. Ioan I. Ică Jr., Sibiu, Edit. Deisis, 1995, p. 31.

${ }^{25}$ Pe Sinai, Dumnezeu se lasă altfel revelat: Videbis quae sunt posteriora Mea„Vei vedea cele dinapoi ale Mele”. Sfântul Irineu de Lyon afirmă două lucruri: faptul că e cu neputință omului să-L vadă de Dumnezeu şi că acesta Îl va vedea mai târziu - in novissimis temporibus - ,în vremurile cele din urmă”, adică în Cuvântul Întrupat (vezi Vladimir Lossky, Vederea lui Dumnezeu..., p. 31).

${ }^{26}$ Sfântul Irineu de Lyon, Adversus Haereses, IV, 20, 2, col. 1033.

${ }^{27}$ Sfântul Grigorie Palama, Contra lui Achindin, P.G., vol. CL, col. 823. 
persoana Sa Mântuitorul nostru Iisus Hristos. Cunoaşterea personală a lui Dumnezeu este un act al libertăţii şi se realizează progresiv, epectatic, cu un anumit efort, în funcție de stadiile apropierii personale: o viață mai puțin pregătită moral pentru întâlnirea cu Hristos denotă o cunoaştere şi o relaţie personală mai subţire. $\mathrm{O}$ pregătire morală asiduă duce la o cunoaştere tot mai apropiată de ioaneicul ,Îl vom vedea precum este” (I In. 3, 2), care constă, după Jürgen Moltmann, ,în participarea neîmpiedicată la viața veşnică, la plinătatea inepuizabilă şi la slava Dumnezeului Treimic Însuşi”28.

\section{Persoana umană în epectază morală}

Ca beneficiar al planului creațional al Sfintei Treimi, care precedă tot ce există şi care este dedicat special lui chiar înainte de a fi fost creat, omul se autorevelează ca o ființă determinată de o gândire existențială superioară (,gândirea-sămânță”, concomitentă cu creația, atribuită Logosului spermaticos), față de care are nişte datorii ființiale imense. Una dintre acestea, esențială, este aceea de a rămâne în contact, în comuniune de energie creațională cu Creatorul, fapt ce implică o multitudine de „mişcări” din sine înspre Dumnezeu, aşa cum Dumnezeu S-a mişcat din Sine înspre om. „Persoana divină şi eternă intră, din proprie inițiativă în comunicare cu omul, dând un fundament şi comuniunii noastre cu semenii" "29, zice Părintele Stăniloae. „Cel Ce ține toate” - Pantokratorul - face primul pas înspre relaționare, trimițând pe Fiul Său Cel Unul-născut ca lumea să-L cunoască şi să intre în legătură personală cu El, omorând „omul cel vechi” şi răscumpărând lumea cu sângele Său.

Omul nu se poate ridica din starea de păcătoşenie decât raportându-se direct la Persoana Mântuitorului Iisus Hristos. Identitatea lui morală îşi are izvorul în Persoana care 1-a răscumpărat

\footnotetext{
28 Jürgen Moltmann, Treimea şi Împărăția lui Dumnezeu. Contribuții la invăţătura trinitară despre Dumnezeu, traducere şi postfaţă de Daniel Munteanu, Alba Iulia, Edit. Reîntregirea, 2007, p. 277.

${ }^{29}$ Pr. Dumitru Stăniloae, op. cit., p. 24.
} 
şi care 1-a dăruit cu forța de a se ridica şi a păşi spre îndumnezeire. Chemarea sa la desăvârşire o face Duhul Sfânt, care continuă lucrarea mântuirii în altă formă decât în cea manifestată de către Hristos. „Toți avem acces la sfințenie, căci toți ne putem uni cu Hristos prin Duhul Sfânt, odată ce Hristos este Fiul lui Dumnezeu,

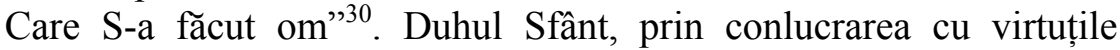
omului $^{31}$, curățeşte persoana umană de excrescențele păcatului şi o alipeşte Persoanei lui Hristos, aducând din nou armonia între creație şi Creator, între creat şi necreat. Sfântul Maxim Mărturisitorul spune că ,persoana umană a fost chemată să unească prin iubire firea creată cu firea necreată, făcându-le să se arate în unitate şi identitate prin dobândirea harului" ${ }^{32}$.

Numai prin înduhovnicire trupul poate ajunge la calitatea de „templu al Duhului Sfânt” (cf. I Cor. 6, 19), iar desăvârşirea trebuie făcută parcurgând câteva etape esențiale de împropriere a virtuților divine în persoana umană cu scopul de a realiza asemănarea cu Dumnezeu. Teologic vorbind, valorile fundamentale ale credintei, transfigurate în procesul de epectază, prin practicarea virtuţilor personale, duc la acel theosis, la îndumnezeire, adică la momentul deplin când atributele lui Dumnezeu sunt transfigurate la propriu, prin virtuțile omului, în persoana sa - creuzetul în care loc această intimă şi de nedescris unire dintre Dumnezeu şi om. Toate acestea sunt posibile pentru că persoana umană este chip al Persoanei divine şi se află într-o continuă relație cu aceasta, pentru că în Persoana divină îşi are izvorul existenței ${ }^{33}$.

\footnotetext{
${ }^{30}$ Ibidem, p. 270.

31 „Virtutea este orientarea obişnuită şi fermă a voinţei şi a întregului caracter de a acționa în feluri specifice şi concrete, adecvate celor aflați în procesul creşterii în chipul lui Hristos şi “theosis” (Irineu Pop Bistrițeanul, op. cit., p. 252).

32 Apud Vladimir Lossky, Teologia mistică..., p. 144.

33 „Ființa noastră nu-şi poate găsi împlinirea ca persoană decât în comuniunea cu o ființă personală superioară, care nu-şi poate descoperi bogăția şi nu poate împlini ființa noastră într-o legătură cu treptele inferioare ei ..., ci într-o relație în care omul însuşi, într-o continuă noutate, îşi însuşeşte, în mod liber şi conştient, infinita bogăție spirituală a Persoanei supreme” (vezi Pr. Dumitru Stăniloae, op. cit., p. 19).
} 
Începutul epectazei persoanei se face prin predarea înaintea lui Dumnezeu. Predarea persoanei umane către Persoana divină este un act de ,autojertfire sfinţitoare, pentru că e o autotranscedere peste tot ce este relativ", cum se exprimă Părintele Stăniloae. Predarea către Creator înseamnă recunoaşterea unei stări de înstrăinare care a degradat chipul personal, deschis înspre comuniune, nu înspre solitudine. Recunoaşterea şi pocăința atrag după sine iertarea: „Numai iertarea de la Persoana absolută îți poate da liniş̧irea totală şi definitivă a conştiinței prin curățirea reală a păcatelor"34. Dumnezeu trezeşte în noi responsabilitatea persoanei noastre în raport cu Persoana Lui, actualizând în noi actul creației, pentru a ne deschide ochii în ceea ce priveşte valoarea morală a persoanei în perspectiva sfințeniei. El intră ,în relație familială cu noi, ca subiect transcendent ${ }^{\prime 35}$.

Existența noastră efemeră prinde curaj în faţa păcatului, atunci când ne alipim de Hristos, Izvorul moral al vieții creştine. Ajutați de puterea Duhului Sfânt, Care ,a restructurat spre chipul mai presus de lume această existență ca Unul Ce a putut să ne facă spre asemănare cu El”36, noi putem să parcurgem urcuşul duhovnicesc spre desăvârşire având permanent alături Persoana lui Hristos ,întru Care putem totul, Care ne întăreşte (cf. Fil. 4, 13). Tot ceea ce facem în relație directă cu Hristos, Duhul Sfânt sfințeşte, pentru că, ontologic, El „susține în starea cea bună existența făcută şi poate să o înfrumusețeze prin relația cu Sine, ducând-o spre asemănarea cu Dumnezeu" 37 .

\footnotetext{
${ }^{34}$ Pr. Dumitru Stăniloae, op. cit., p. 276.

${ }^{35}$ Ibidem, p. 268.

${ }^{36}$ Sfântul Chiril al Alexandriei, Scrieri. Partea a III-a. Despre Sfânta Treime, în col. P.S.B., vol. 40, traducere, introducere şi note de Pr. Dumitru Stăniloae, Bucureşti, EIBMBOR, 1994, p. 298.

${ }^{37}$ Sfântul Chiril al Alexandriei, op. cit., p. 298.
} 


\section{5. În Hristos şi în Biserică - persoana ca parte integrantă a conştiinței misionare a Bisericii}

Persoana umană, impregnată de calități divine, este o sumă de însuşiri şi relații comunionale care îi definesc identitatea eclezială. Dumnezeu, fiind subzistență tripersonală, dăruieşte omului darul deschiderii spre comuniune numai în Biserică, pentru că Biserica „este lumea reconciliată”,38, după expresia Fericitului Augustin. Dacă din punct de vedere social şi identitar, persoana se află într-o continuă stare de relaționare, ca un dat ontologic, ea deține un rol foarte important în eclesiologie. Spiritual vorbind, persoana este factorul de misiune cel mai important în Biserică, pentru că totul o vizează; ea a fost chemată să devină "o Biserică tainică"39. În Biserică, persoana este acasă, în apropierea inefabilă a Arhetipului. Ea este „deținătoarea adresei lui Dumnezeu”, capabilă să-L cunoască prin comuniunea eclezială ${ }^{40}$ şi, cunoscându-L, să se deschidă şi înspre ceilalți. Atributul ei misionar e dat de trăirea ca mădular al Trupului mistic al lui Hristos - Biserica -, în sânul căreia primeşte „har peste har” (In. 1, 16), ca beneficiar al Sfintelor Taine, în special al Euharistiei.

Biserica activează conştiința misionară a persoanei în Sfânta Liturghie. Numai în Biserică, persoana îşi îndeplineşte în mod complet activismul misionar, după modelul treimic, fundamentat pe iubirea inter-personală: „Teologia misiunii este întotdeauna rodul ființei totale a Bisericii ... Duhul Sfânt este principiul comuniunii. Botezul permite fiecărui membru al Trupului lui Hristos de a fi în comuniune cu toți cei

\footnotetext{
38 Apud Charles Journet, Théologie de l'Église, Paris, Edit. Desclée de Brouwer, 1958, p. 381.

${ }^{39}$ Sfântul Maxim Mărturisitorul, Mistagogia 4, P.G. 91, 672 B.

${ }^{40}$ „Forma proprie a unitătii Bisericii este comuniunea ... Manifestarea plenară a mijlocirii Cuvântului Intrupat va fi, în acelaşi timp şi în mod necesar, manifestarea plenară a unității de comuniune" (vezi Pr. Mihai Himcinschi, Misiune şi dialog. Ontologia misionară a Bisericii din perspectiva dialogului interreligios, Alba Iulia, Edit. Reîntregirea, 2003, pp. 34-35).
} 


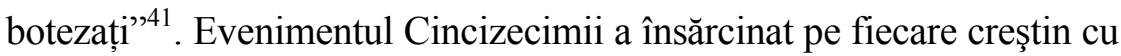
destinul misionar de a-L face cunoscut pe Hristos intra şi extra ecclesia. După modelul misionar al iubirii intra-treimice, Biserica a dezvoltat un caracter misionar care însărcinează fiecare membru cu responsabilități a căror împlinire îl definesc ca „fiu al învierii”, ca mădular al Trupului lui Hristos, ca persoană care se mântuieşte prin celălalt, aşa cum ne-a învățat Hristos. „Persoana absolută a devenit în Hristos şi persoana umanului, comunicând celor ce cred în El pe Duhul Său cel Sfânt, sau sălăşluindu-Se prin aceasta Ea însăşi în ei"’42.

\section{Concluzii}

Identitatea morală a persoanei umane este dată de către Persoana Creatorului, Cel Care a imprimat în uman „chipul” şi „asemănarea” Lui. Sfântul Ioan Gură de Aur, întărind ideea nevoii întipăririi chipului divin în ființa omului, spune că acesta din urmă ar trebui să fie preocupat numai de asemănarea cu Creatorul, „culmea cea mai înaltă a virtuții”. Iar Sfântul Chiril al Alexandriei spune că „firea omului şi dezvoltarea ei nu ajunge la desăvârşirea potrivită ei, decât abia când s-a îmbogățit cu întipărirea chipului dumnezeiesc în ea prin Duhul" "43, după ce se identifică cu Creatorul. Întipărirea chipului dumnezeiesc este un proces moral cu o structură interioară şi de o durată atât de intimă, încât ar trebui raportat la fiecare persoană în parte, de aceea creşterea morală a unei persoane nu este cuantificabilă matematic, ci este definită mai mult de calitatea relației cu aproapele - „celălalt chip al lui Dumnezeu”, într-o libertate în Duhul Sfânt, o libertate creativă, care edifică duhovniceşte. Mai mult, ,actul moral liber se poate realiza nu doar în ceea ce priveşte viața numită morală, ci şi în întreaga viață a omului - în tot ceea ce

\footnotetext{
${ }^{41}$ Pr. Aurel Pavel, Misiunea Bisericii şi ecumenismul, în vol. „Elemente de istorie, doctrină şi practică misionară: o perspectivă ecumenică" (coord. Pr. Nicolae Moşoiu), Sibiu, Edit. Universității „Lucian Blaga”, 2006, p. 45.

${ }^{42}$ Pr. Dumitru Stăniloae, op. cit., p. 276.

${ }^{43}$ Sfântul Chiril al Alexandriei, op. cit., p. 298.
} 
face el, cu tot ceea ce se identifică el (n.n.); în consecință, el este legat de plenitudinea vieții spirituale", zice filosoful N. Berdiaev ${ }^{44}$.

Biserica este locul în care persoana intră în actualitate, în comuniunea eclezială. Actualizarea „chipului” începe în Biserică, la Taina Sfântului Botez, când omul primeşte forța de a lupta contra fascinației răului. În Sfintele Taine, persoana participă ca membru al Trupului mistic al lui Hristos, la acțiunea restauratoare a Euharistiei. Raportându-se moral la Persoana lui Iisus Hristos, ca membru al Trupului Său, persoana participă la comuniunea Sfintei Treimi, înnoindu-şi în mod permanent conştiința misionară. În sânul Bisericii, persoana ajunge la theosis ${ }^{45}$ - îndumnezeirea, devenirea întru ,asemănare”. „Asemănarea” înseamnă a regăsi identitatea morală a persoanei în sânul eclezial, în Biserică, unde se întâlnesc comuniunea interpersonală cu comuniunea treimică. „Asemănarea” înseamnă a deveni întru totalitatea ființei şi a persoanei, înseamnă să ducem persoana la Persoana creatoare, să ajungem, atât cât stă în putinţă ființei omeneşti, asemenea cu Dumnezeu, prin virtuți: „Fiți asemenea Tatălui vostru Cel din ceruri” (Mt. 5, 45), să ajungem la „măsura bărbatului desăvârşit” (Efes. 4, 13).

\section{References:}

- Berdiaev, Nikolai, Despre menirea omului. Încercare de etică paradoxală, trad. de Daniel Hoblea, Oradea, Edit. Aion, 2004;

- Bistrițeanul, Irineu Pop, Chipul lui Hristos în viața morală a creştinului, Cluj-Napoca, Edit. Renaşterea, 2001;

- Dinu, M., Fundamentele comunicării interpersonale, Bucureşti, Edit. All, 2004;

${ }^{44}$ Nikolai Berdiaev, Despre menirea omului. Incercare de etică paradoxală, trad. de Daniel Hoblea, Oradea, Edit. Aion, 2004, p. 28.

45 „Theosis - acel infinit proces prin care Duhul Sfânt ne transformă şi ne transfigurează în slava lui Hristos - începe ... în mijlocul slăbiciunii noastre. Acest proces este adevărata viaţă şi precondiția necesară pentru ca Biserica să medieze viața lui Hristos către lume" (Irineu Pop Bistrițeanul, op. cit., p. 283). 
- Enciclopedie de filozofie şi ştiințe umane, București, Edit. All, 2004;

- Evdochimov, Paul, Ortodoxia, trad. de Dr. Irineu Popa, Arhiereu vicar, Bucureşti, EIBMBOR, 1996;

- Galeriu, Pr. Constantin, Jertfă şi răscumpărare, Bucureşti, Edit. Harisma, 1991;

- Hierotheos, Mitropolit de Nafpaktos, Persoana în tradiția ortodoxă, trad. de Prof. Paul Bălan, Bacău, Edit. Bunavestire, 2002;

- Himcinschi, Pr. Lect. Dr. Mihai, Misiunea Bisericii intr-o societate abundent capitalizată, în vol. „Spiritualitate şi consumism în Europa unită”, Alba Iulia, Edit. Reîntregirea, 2004;

- ***, Misiune şi dialog. Ontologia misionară a Bisericii din perspectiva dialogului interreligios, Alba Iulia, Edit. Reîntregirea, 2003;

- Journet, Charles, Théologie de l'Église, Paris, Edit. Desclée de Brouwer, 1958;

- Lossky, Vladimir, Teologia mistică a Bisericii de Răsărit, Bucureşti, Edit. Anastasia, f.a.;

- ***, Vederea lui Dumnezeu, trad. de Maria-Cornelia Oros, studiu introductiv de diac. Ioan I. Ică Jr., Sibiu, Edit. Deisis, 1995;

- ***,După chipul şi asemănarea lui Dumnezeu, Bucureşti, Edit. Humanitas, 2006;

- Moltmann, Jürgen, Treimea şi Împărăția lui Dumnezeu. Contribuții la invățătura trinitară despre Dumnezeu, traducere şi postfață de Daniel Munteanu, Alba Iulia, Edit. Reîntregirea, 2007;

- Nellas, Panayotis, Omul - animal îndumnezeit. Perspective pentru o antropologie ortodoxă, Sibiu, Edit. Deisis, 1999;

- Pavel, Pr. Aurel, Misiunea Bisericii şi ecumenismul, în vol. „Elemente de istorie, doctrină şi practică misionară: o perspectivă ecumenică" (coord. Pr. Nicolae Moşoiu), Sibiu, Edit. Universității „Lucian Blaga”, 2006;

- Remete, George, Ființa şi credința, vol. I, Ideea de ființă, Bucureşti, Edit. Academiei Române, 2012;

- Sfântul Chiril al Alexandriei, Scrieri. Partea a III-a. Despre Sfânta Treime, în col. P.S.B., vol. 40, traducere, introducere şi note de Pr. Dumitru Stăniloae, Bucureşti, EIBMBOR, 1994;

- Sfântul Grigorie Palama, Contra lui Achindin;

- Sfântul Ioan Damaschin, Dogmatica, cartea a III-a, trad. de Dumitru Fecioru, Bucureşti, EIBMBOR, 2005;

- Sfântul Irineu de Lyon, Adversus Haereses; 
- Stăniloae, Pr. Dumitru, Teologia Dogmatică Ortodoxă, vol. 1, Bucureşti, EIBMBOR, 2003;

- Yannaras, Christos, Persoană şi eros, Bucureşti, Edit. Anastasia, 2000. 